\title{
Innovation-oriented resource management model proposed on the basis of the methodology of economic assessment of resource capabilities of oil and gas industry contractors
}

\author{
Inna Vinokur $^{1 *}$, Svetlana Ponomareva ${ }^{1}$ \\ ${ }^{1}$ Perm National Research Polytechnic University, 29, Komsomolsky ave., Russia, 614990, Perm
}

\begin{abstract}
The paper presents an innovation-oriented model of resource management, which was built on the basis of the methodology of economic assessment of resource capabilities of contracting companies of the oil and gas industry. Assessment and choice of resource capabilities of contracting companies is the most important scientific problem of large companies and enterprises of the oil and gas industry when purchasing material resources. Currently, the increase in the supply of the same type of resources exacerbates the problem of choice. Thus, a large number of algorithms, methods and other procedures were developed to select organizations that supply resources. However, there are not enough comprehensive tools to assess the feasibility of selecting a supplier taking into account factors that allow evaluating suppliers of a certain industry. The purpose of the study is to create an innovative resource management model based on the methodology of economic justification for choosing resource suppliers for oil and gas enterprises. The object of the study is enterprises and large companies of the oil and gas industry. The subject of the study is effective resource management based on the methodology of economic assessment of the resource capabilities of contracting companies.
\end{abstract}

\section{Introduction}

Scientific research provides a suggested list of basic criteria according to which a preliminary list is formed at the second stage of the above selection procedure: company size; cost competitiveness; domestic/foreign supplier; financial condition; availability of local (in this country) support; location; producer/distributor; market share; supplier relationship history; quality reputation; recommendations from other clients; the only (exclusive) supplier.

\section{Materials and methods}

In order to find new contracting companies for the supply of resources, the following well-known methods are mainly used: ranking method (the main criteria for evaluating the supplier are selected, then the employees of the procurement service and (or) other departments, possibly engaged experts, establish their importance by expertise. The ranking value for each criterion is calculated by producing the specific weight of the criterion for its expert point assessment (for example, for a 10-point system) for this supplier. Then the obtained ranking values are summed up according to all criteria and the final $\mathrm{R}_{\mathrm{i}}$ ranking for a specific $i$ supplier is obtained); cost estimation method or cost-factor method (mission method) (all possible costs and revenues are calculated for each supplier (logistics risks are taken into account). Then, from the set of options (missions), the most profitable (according to the criterion of total profit) is selected. In fact, this is a kind of method of ranking criteria by value; the method of dominant characteristics (focusing on one selected parameter (criteria). This parameter may be the lowest price, the best quality, the delivery schedule, inspiring the most confidence, etc. The advantage of this method is its simplicity, and the disadvantage is the ignorance of the remaining selection criteria); the method of preference categories (evaluation of the contracting company, including the choice of the evaluation method, depends on information obtained from many divisions of the company. Engineering services give their assessment of the supplier's ability to produce high-tech products and may competently judge its quality, the dispatching service reports on the timeliness of delivery of purchased material resources, production departments of the company - on the simplicity and convenience of direct use of material resources in the production process. The use of such a method implies the availability of information from many sources - a vast and diverse information base that considers each factor on an equal basis along with others, while for a company, perhaps some factor is key, for example, the ease of using products in the production process); the fuzzy set theory (the process of selecting a supplier is carried out on the basis of a wide range of evaluation criteria). The study develops a two-level hierarchical structure of a fuzzy model. The model uses fuzzy inference for intermediate variables to then pass

\footnotetext{
*Corresponding author: Innavinokur12345@mail.ru
} 
clear values of these variables to systems at the subsequent hierarchy level).

The importance of selecting a supplier is explained not only by the activities of a large number of suppliers of homogeneous products, but also by the fact that the supplier must be, first of all, a reliable partner who participates in the implementation of its trading strategy. Supplier selection consists of the following main stages: 1) definition of customer requirements; 2) search for suppliers; 3) identification of potential suppliers; 4) preliminary assessment; 5) basic evaluation using the chosen methodology; 6) supplier selection; 7) monitoring and evaluation of works performed. One of the most important stages is "conducting a basic assessment using the chosen methodology". When making a decision at this stage, there are some difficulties, since suppliers have a different set of properties, which sometimes have a dual meaning: some indicators have good ranking, and others - bad.

\section{Results and Discussion}

In all the theoretical articles analyzed, the following are identified as the main evaluation criteria: price; price policy flexibility; terms of payment; product quality; availability of free production facilities; level; business activity of the enterprise; speed of supply of resources; supplier participation in innovative R\&D; duration of the supplier's presence on the market; market reputation of the enterprise; company size; domestic/foreign supplier.

Scientists around the world are actively discussing the problems of supplying quality resources from various contracting companies, among the scientific works the contribution of the following authors should be highlighted: Andiani, F.M., Abid, F., Hendri, Girsang, A.S. Business intelligence for generating comprehensive report in electronic completion and handover [1]; Bigelow, L.S., Barney, J.B. What can Strategy Learn from the Business Model Approach [2]; Biskupska, D., Chandima Ratnayake, R.M. On the Need for Effective
Lean Daily Management in Engineering Design Projects: Development of a Framework [3]; Cartwright, S., Davies, I., Archer-Brown, C. Managing relationships on social media in business-to-business organizations [4]; Colucci, M., Vecchi, A. Close the loop: Evidence on the implementation of the circular economy from the Italian fashion industry [5]; Dell'Era, C., Trabucchi, D., Magistretti, S. Exploiting incumbents' potentialities: From linear value chains to multisided platforms [6]; Frandsen, T., Boa, S.Ø., Raja, J.Z. Pricing structures for solutions: an exploratory study within the oil and gas industry [7]; Haaskjold, H., Andersen, B., Lædre, O., Aarseth, W. Factors affecting transaction costs and collaboration in projects [8]; Mejlænder-Larsen, Ø. A three-step process for reporting progress in detail engineering using BIM, based on experiences from oil and gas projects [10]; Nurcahyo, R., Dody, P.N., Yadrifil, Z.Z.Z., Habiburrahman, M., Wibowo, N. CRM dimensional analysis and ANP method for oil and gas industry sub-contractor in indonesia in the context of reducing customer complaints [11]; Ponomareva, S.V., Kutuzova, V.S. \& Pavlovich, A.A. Calculation of Uncerta inties in Operating Strapdown Inertial Navigation Systems on Mobile Objects [12]; Ponomareva, S.V., Zheleznova I.V. Intrafirm Planning and mathematical modeling of Owner's Equity in Industrial Enterprises [13]; Sund, K.J., Bogers, M.L.A.M., Sahramaa, M. Managing business model exploration in incumbent firms: A case study of innovation labs in European banks [14]; Wood, S. Developments in the HRM-Performance Research stream: The mediation studies [15]; Zulhafiz, W.M., Rahman, N.B.A. Unfair risk allocation in oil and gas upstream service contracts in malaysia: The necessity for oilfield anti-indemnity act [16].

In order to identify the most significant criteria, it is necessary to conduct an expert assessment under the conditions of the rating method. Let us use a 10-point scale (Table 1).

Table 1. Expert assessments of the weight of criteria

\begin{tabular}{|c|c|c|c|c|c|c|c|c|c|c|c|}
\hline \multirow{2}{*}{ Criteria } & \multicolumn{10}{|c|}{ Experts } & \multirow{2}{*}{ Total } \\
\hline & 1 & 2 & 3 & 4 & 5 & 6 & 7 & 8 & 9 & 10 & \\
\hline Price & 8 & 8 & 5 & 9 & 7 & 9 & 9 & 6 & 7 & 9 & 77 \\
\hline Price policy flexibility & 9 & 9 & 7 & 8 & 7 & 7 & 7 & 8 & 7 & 8 & 77 \\
\hline Payment terms & 7 & 7 & 9 & 8 & 7 & 7 & 5 & 7 & 8 & 9 & 74 \\
\hline Product quality & 9 & 9 & 7 & 9 & 9 & 7 & 7 & 8 & 8 & 6 & 79 \\
\hline $\begin{array}{lll}\text { Availability of } & \text { free } \\
\text { production capacities }\end{array}$ & 9 & 9 & 6 & 8 & 8 & 6 & 6 & 5 & 6 & 6 & 69 \\
\hline Reliability level & 9 & 9 & 10 & 9 & 7 & 6 & 6 & 7 & 7 & 8 & 78 \\
\hline $\begin{array}{l}\text { Business activity of the } \\
\text { enterprise }\end{array}$ & 7 & 7 & 9 & 9 & 6 & 9 & 7 & 5 & 7 & 9 & 75 \\
\hline Delivery speed & 8 & 8 & 6 & 8 & 9 & 5 & 6 & 6 & 5 & 7 & 68 \\
\hline $\begin{array}{l}\text { Supplier participation in } \\
\text { innovative R\&D }\end{array}$ & 6 & 6 & 2 & 6 & 8 & 3 & 3 & 2 & 3 & 2 & 41 \\
\hline Supplier market time & 8 & 8 & 9 & 9 & 6 & 5 & 5 & 6 & 6 & 5 & 67 \\
\hline $\begin{array}{l}\text { Market reputation of the } \\
\text { enterprise }\end{array}$ & 9 & 10 & 9 & 10 & 7 & 6 & 6 & 7 & 8 & 9 & 81 \\
\hline Company size & 8 & 8 & 6 & 9 & 7 & 6 & 6 & 5 & 5 & 6 & 66 \\
\hline Domestic/foreign supplier & 9 & 9 & 10 & 9 & 7 & 6 & 6 & 4 & 7 & 9 & 76 \\
\hline
\end{tabular}

Let us calculate the average importance of the criterion: price -7.7 ; price policy flexibility -7.7 ; payment terms -7.4 ; product quality -7.9 ; availability of free production capacities -6.9 ; reliability level - 
7.8; business activity of the enterprise -7.5 ; delivery speed - 6.8; supplier participation in innovative R\&D 4.1; supplier market time - 6.7; market reputation of the enterprise - 8.1; company size - 6.6; domestic/foreign supplier - 7.6.

The data in Table 1 show that the most important criterion for selecting a supplier is the "market reputation of the enterprise" - 8.1, and less important "supplier/contracting company participation in innovative R\&D" - 4.1. As a result of the analysis of supplier evaluation methods, the best supplier evaluation method was identified - fuzzy set theory. This method is complex for prompt processing of information and requires re-equipping the software product and computer base.

The method used at the moment by most oil and gas enterprises is a tender, and according to experts, it is not the best way to evaluate contracting companies. Based on the above arguments, it is possible to conclude that it is necessary to develop and form a method for evaluating resource contracting companies. The combination of fuzzy set theory and the ranking method may be very useful, because only ordinal estimation (ranking) is required, and at the same time the experts feel more comfortable with it, while the fuzzy set theory is suitable to face uncertainty in decision-making in this area.

Let $y$ be a finite set of valid actions labeled as $\left\{\mathrm{y}_{1}\right.$, $\left.\mathrm{y}_{2}, \ldots, \mathrm{y}_{\mathrm{m}}\right\} . A$ may be considered as a set of objects, solutions, alternatives, events or candidates.

Let us suppose that it is possible to analyze the effects of actions using a set of criteria. Then $C$ is a set of criteria denoted as $\mathrm{C}=\left\{\mathrm{C}_{1}, \mathrm{C}_{2}, \ldots, \mathrm{C}_{\mathrm{n}}\right\}$. The following stages were developed in an paper to rank the alternative using a new technique:

Stage 1 - projection of separation of alternatives. At this stage, alternatives $\left(\mathrm{y}_{\mathrm{i}}\right)$ and criteria $\left(\mathrm{C}_{\mathrm{j}}\right)$ should be ranked based on verbal language variables. For example, $A_{1}$ is much better (verbal language variable) than $A_{2}$, if, according to experts, $A_{1}$ is in much better situation than $A_{2}$. Thus, alternatives and criteria may be projected using verbal language variables: "Much better" (MB), "Better" (B) and "Equal" (E). If necessary, verbal language variables may be increased in projection.

Stage 2 - creation of the accessory function. Now that verbal language variables are used in the projection, it is necessary to define their membership functions with experts in the relevant research area.

Stage 3 - primary ranking $\left(r_{j}^{\prime}\right.$ and $\left.r_{j}\left(y_{i}\right)\right)$. In each projection, we assign the value 1 to the first (best). The remaining estimates are calculated by adding the ratio values (fuzzy number) to the last. For example, if based on criterion $1\left(\left(\mathrm{C}_{1}\right), \mathrm{y}_{1}\right.$ is $\mathrm{MB}$ than $\mathrm{y}_{3}\left(\mathrm{MB}^{\prime}=(0.2 ; 0.7\right.$; $1)), r^{\prime}{ }_{1}\left(y_{1}\right)=1$ and $r_{2}{ }_{2}\left(y_{2}\right)=(1.2 ; 1.7 ; 2)$. This process must be repeated until $\mathrm{r}_{\mathrm{j}}$.

Stage 4 - estimated distance $\left(d^{\prime}{ }_{j}\left(0, y_{j}\right)\right)$. This process must be repeated according to all criteria.

Stage 5 - absolute ranking $\left(R_{j}\left(y_{i}\right)\right) . \mathrm{R}_{\mathrm{j}}\left(\mathrm{y}_{\mathrm{i}}\right)-$ average ranking for the $i$ alternative and $j$ criteria, such as $\mathrm{R}_{1}\left(\mathrm{y}_{1}\right) \leq \mathrm{R}_{2}\left(\mathrm{y}_{2}\right)$, if $\mathrm{d}_{1}{ }_{1}\left(0, \mathrm{y}_{1}\right) \leq \mathrm{d}_{2}\left(0, \mathrm{y}_{2}\right)$.
Stage 6 - aggregation $\left(R\left(y_{i}\right)\right)$. At this stage, the ranking method is used according to the absolute ranking of alternatives for each criterion: $R\left(y_{i}\right)=R_{i}$.

The final ranking is carried out according to $\mathrm{R}\left(\mathrm{y}_{\mathrm{i}}\right)$.

This technique is easy to use in comparison with the fuzzy set theory. At the same time, it may study more data, and it is also more objective than the ranking method. The model may be used to evaluate the following indicators: objects, solutions, alternatives, events or candidates.

After the development of the new method, the ranking method, the fuzzy set theory and the new supplier assessment method proposed in the paper are comparable (Table 2).

Table 2. Comparative characteristics of contracting company selection methods

\begin{tabular}{|l|l|l|l|}
\hline Characteristics of methods & 1 & 2 & 3 \\
\hline Usability & 3 & 2 & 3 \\
\hline $\begin{array}{l}\text { Amount of information to be } \\
\text { analyzed }\end{array}$ & 1 & 3 & 3 \\
\hline Financial costs & 3 & 2 & 2 \\
\hline Applicability to any enterprise & 3 & 3 & 3 \\
\hline Time input & 3 & 2 & 2 \\
\hline Objectivity & 1 & 3 & 3 \\
\hline Total $(\mathbf{Q i j})$ & 14 & 15 & 16 \\
\hline
\end{tabular}

Table 2 shows that the generalizing measure of the characteristics of the methods indicates the best effectiveness of the method and amounts to 16 points.

Table 3. Summary of advantages and disadvantages of two contractor's resource evaluation methods

\begin{tabular}{|c|c|}
\hline Tender & New methodology \\
\hline \multicolumn{2}{|l|}{ Advantages } \\
\hline $\begin{array}{l}\text { - transparency of company } \\
\text { information; } \\
\text { - work with verified contracting } \\
\text { companies; } \\
\text { - payment delay. }\end{array}$ & $\begin{array}{l}\text { - transparency of company } \\
\text { information; } \\
\text { - work with new suppliers } \\
\text { identified in the market analysis; } \\
\text { - self-selection of a supplier by } \\
\text { meaningful criteria }\end{array}$ \\
\hline \multicolumn{2}{|l|}{ Disadvantages } \\
\hline $\begin{array}{l}\text { - steep demand for entry } \\
\text { requirements; } \\
\text { - price dumping; } \\
\text { - lack of supply market analysis } \\
\text { of; } \\
\text { - corruption; } \\
\text { - absence of personal contacts; } \\
\text { - complex and lengthy process } \\
\text { between application and } \\
\text { confirmation. }\end{array}$ & $\begin{array}{l}-\quad \text { relative complexity of } \\
\text { calculations }\end{array}$ \\
\hline
\end{tabular}

In this case, the following subjects are also taken into account: leadership of the enterprise, employees of the procurement department, employees of the planning and economic department and employees of the legal department. The company of the Oil and Gas Industry identified the problem of choosing a contracting company. The current methodology (tender) does not quite suit the managers of the procurement department. After a survey of experts, a 
summary table of advantages and disadvantages of the two methods of evaluating a resource supplier was compiled: a tender and a new methodology for evaluating contracting companies (Table 3 ).

Let us consider the developed methodology for the company of the Oil and Gas Industry. At the first stage let us determine the list of resource suppliers for the company: Weatherford, Tatneft, Top-Co, ZERS, ArtOsnastka. At the second stage, let us evaluate the suppliers according to the previously selected criteria Table 4. Primary ranking*
(Table 1) in accordance with the average importance of the criterion and determine the ranking of the criteria for evaluating the contracting companies for the supply of resources. The data was generated after expert evaluation of suppliers by the company's procurement department managers. The next stage is to match suppliers against the criteria and assign a primary ranking to each of them (Table 4).

\begin{tabular}{|c|c|c|c|c|c|c|c|c|c|c|c|c|c|c|c|c|c|c|c|c|c|c|c|c|c|c|c|c|c|c|c|c|c|c|c|c|c|}
\hline & & $y_{1}$ & & & $y_{2}$ & & & $y_{3}$ & & & & & & 5 & & & 86 & & & $y_{7}$ & & $y$ & & & $y_{9}$ & & & $y_{10}$ & & & 11 & & $y$ & 12 & & $y_{13}$ & \\
\hline $\begin{array}{l}\text { Weather } \\
\text { ford }\end{array}$ & 2 & 2.5 & 2.9 & 1 & 1 & 1 & 1.6 & 1.8 & 2 & 2.4 & 1. & 3.6 & 2 & 2.5 & 2.9 & 3.2 & 4. & 4.7 & 1.4 & \begin{tabular}{l|l}
1.6 & 1
\end{tabular} & .72 & $\begin{array}{l}24 \\
3 .\end{array}$ & 13. & 2.8 & 3.6 & 4.1 & 1 & 1 & 1 & 1 & 1 & 1 & \begin{tabular}{l|l}
2 & 2.
\end{tabular} & \begin{tabular}{ll|l|}
4 & 2.7
\end{tabular} & 1.6 & 1.8 & 2 \\
\hline Tatneft & 1 & 1 & 1 & 1.6 & 1.8 & 2 & 2 & 2.5 & 2.9 & 1 & I & 1 & 2.4 & 3.1 & 3.6 & 2.6 & 3.2 & 3.7 & 1 & 1 & 1 & \begin{tabular}{l|l}
.6 & 1.
\end{tabular} & \begin{tabular}{l|l}
9 & 2.2
\end{tabular} & 1 & 1 & 1 & 1.6 & 1.8 & 2 & 2.4 & 3.1 & 3.6 & \begin{tabular}{l|l}
1.4 & 1.
\end{tabular} & $6|6| 1.7 \mid$ & 2.4 & 3 & \\
\hline Top-Co Inc & 2 & 2.4 & 2.7 & 2.2 & 2.6 & 3 & 1 & 1 & 1 & 1.6 & 8 & 2 & 1 & 1 & 1 & 1 & 1 & 1 & 2 & 2.42 & 2.7 & 1 & \begin{tabular}{l|l}
1 & 1.2
\end{tabular} & 1.8 & 2.2 & 2.4 & 2 & 2.4 & 2.7 & $1.6 \mid 1$. & 1.8 & 2 & \begin{tabular}{l|l}
1 & 1 \\
\end{tabular} & \begin{tabular}{l|l|}
1 & 1
\end{tabular} & 1 & 1 & 1 \\
\hline ZERS & 1.6 & 1.8 & 2 & 2.2 & 2.7 & 3.2 & 2 & 2.4 & 2.7 & 2 & 4 & 2.7 & 1.6 & 1.8 & 2 & 2 & 2.4 & 2.7 & 1.4 & \begin{tabular}{l|l}
1.6 & 1
\end{tabular} & 1.7 & 1 & 1 & 2.2 & 2.8 & 3.1 & 2 & 2.5 & 2.9 & 2 & 24 & 2.7 & \begin{tabular}{l|l}
2.4 & 3
\end{tabular} & \begin{tabular}{l|l|}
3 & 3.4 \\
\end{tabular} & 3 & 3.8 & \\
\hline & & & & & & & & & & 2 & & & .6 & & & & & 1.7 & 2 & & & 2 & 2. & 1.4 & 1.6 & 1.7 & 2.4 & 3.1 & 3.6 & 2 & 2.5 & & & $\begin{array}{llll}6 & 4.1\end{array}$ & 2 & 2.4 & \\
\hline
\end{tabular}

*The primary ranking is assigned by experts (specialists of the company's procurement department).

Table 4 shows that the experts determined that the Weatherford is "much better" than other companies by the criteria of price policy flexibility, the duration of the supplier's presence in the market, the market reputation of the enterprise; Tatneft - price, product quality, business activity of the enterprise, supplier's participation in innovative $\mathrm{R} \& \mathrm{D}$; Top-Co - payment terms, availability of free production capacity, reliability level, company size, domestic/foreign supplier; ZERS - delivery speed; Art-Osnastks - does not have a criterion to which a primary ranking would be assigned.

After determining the primary ranking, let us present the distance estimate for each criterion (Table 5).

Table 5. Distance estimation for each criterion

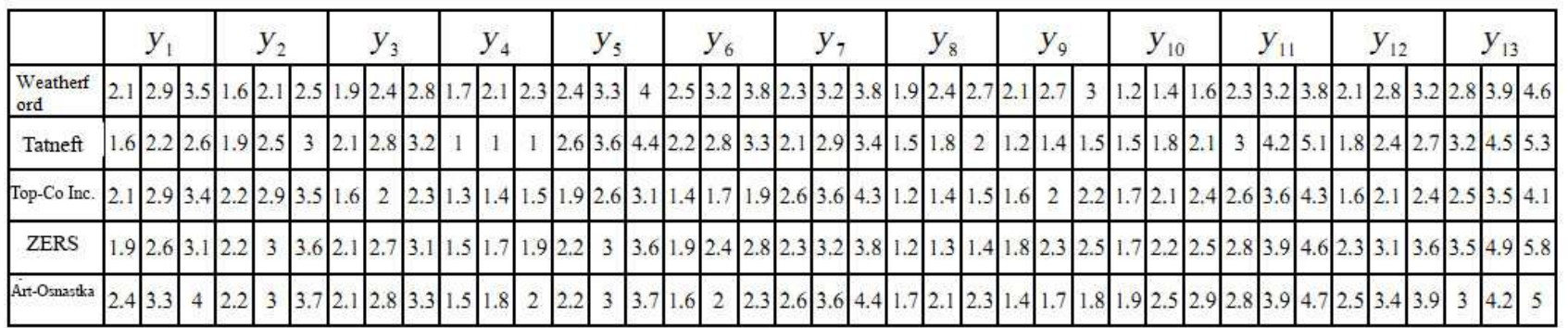

Now that the distance is determined, let us calculate the absolute values of the ranking with aggregation (Table 6).

Table 6. Calculation of absolute ranking values with aggregation

\begin{tabular}{|l|l|l|l|l|l|l|l|l|l|l|l|l|l|}
\hline $\begin{array}{l}\text { Contracting } \\
\text { company }\end{array}$ & $\begin{array}{l}\mathrm{R}_{1} \\
\left(\mathrm{~A}_{\mathrm{i}}\right)\end{array}$ & $\begin{array}{l}\mathrm{R}_{2} \\
\left(\mathrm{~A}_{\mathrm{i}}\right)\end{array}$ & $\begin{array}{l}\mathrm{R}_{3} \\
\left(\mathrm{~A}_{i}\right)\end{array}$ & $\begin{array}{l}\mathrm{R}_{4} \\
\left(\mathrm{~A}_{i}\right)\end{array}$ & $\begin{array}{l}\mathrm{R}_{5} \\
\left(\mathrm{~A}_{i}\right)\end{array}$ & $\begin{array}{l}\mathrm{R}_{6} \\
\left(\mathrm{~A}_{i}\right)\end{array}$ & $\begin{array}{l}\mathrm{R}_{7} \\
\left(\mathrm{~A}_{i}\right)\end{array}$ & $\begin{array}{l}\mathrm{R}_{8} \\
\left(\mathrm{~A}_{i}\right)\end{array}$ & $\begin{array}{l}\mathrm{R}_{9} \\
\left(\mathrm{~A}_{i}\right)\end{array}$ & $\begin{array}{l}\mathrm{R}_{10} \\
\left(\mathrm{~A}_{i}\right)\end{array}$ & $\begin{array}{l}\mathrm{R}_{11} \\
\left(\mathrm{~A}_{\mathrm{i}}\right)\end{array}$ & $\begin{array}{l}\mathrm{R}_{12} \\
\left(\mathrm{~A}_{i}\right)\end{array}$ & $\begin{array}{l}\mathrm{R}_{13} \\
\left(\mathrm{~A}_{\mathrm{i}}\right)\end{array}$ \\
\hline Weatherford & 42 & 21 & 27 & 16 & 51 & 49 & 47 & 25 & 32 & 5.5 & 47 & 34 & 59 \\
\hline Tatneft & 21 & 30 & 34 & 1 & 56 & 38 & 38 & 9.5 & 3 & 12 & 62 & 25 & 64 \\
\hline Top-Co Inc. & 38 & 42 & 16 & 5.5 & 30 & 9.5 & 56 & 3 & 13 & 21 & 56 & 16 & 53 \\
\hline ZERS & 30 & 42 & 34 & 9.5 & 42 & 27 & 47 & 3 & 23 & 21 & 59 & 44 & 65 \\
\hline Art-Osnastka & 51 & 44 & 38 & 9.5 & 44 & 16 & 56 & 16 & 7 & 27 & 59 & 51 & 62 \\
\hline
\end{tabular}

After calculating the distance and absolute value of the ranking with aggregation, it is necessary to represent the weighted normalized matrix (Table 7).

Table 7. Aggregation summary

\begin{tabular}{|c|c|c|c|c|c|c|c|c|c|c|c|c|c|}
\hline & $R_{1}\left(A_{i}\right)$ & $R_{2}\left(A_{i}\right)$ & $R_{3}\left(A_{i}\right)$ & $R_{4}\left(A_{i}\right)$ & $R_{5}\left(A_{i}\right)$ & $R_{6}\left(A_{i}\right)$ & $R_{7}\left(A_{i}\right)$ & $R_{\mathrm{s}}\left(A_{\mathrm{\gamma}}\right)$ & $R_{9}\left(A_{i}\right)$ & $R_{10}\left(A_{i}\right)$ & $R_{11}\left(A_{i}\right)$ & $R_{12}\left(A_{i}\right)$ & $R_{13}\left(A_{i}\right)$ \\
\hline & 0.4967 & 0.2546 & 0.3921 & 0.7398 & 0.5016 & 0.6986 & 267 & 7949 & 585 & 302 & 698 & 4193 & 343 \\
\hline Tatneff & 0.2484 & 0.3637 & 0.4938 & 0.0462 & 0.5508 & 0.5417 & 0.3450 & 0.3020 & 0.0711 & 0.2840 & 0.4879 & 0.3083 & 0.4711 \\
\hline$\overline{C o \text { Itec }}$ & 0.4494 & 0.5091 & 0.2324 & 0.2543 & 0.2951 & 0.1354 & 0.5084 & 0.0954 & 0.3081 & 0.4970 & 0.4406 & 0.1973 & 0.3901 \\
\hline ZERS & 0.3548 & 0.5091 & 0.4938 & 0.4393 & 0.4131 & 0.3849 & 0.4267 & 0.0954 & 0.5452 & 0.4970 & 0.4643 & 0.5427 & 0.4785 \\
\hline -0isastite. & 0.6031 & 0.5334 & 0.5519 & 0.4393 & 0.4328 & 0.2281 & 0.5084 & 0.5087 & 0.1659 & 0.6390 & 0.4643 & 0.6290 & 0.4564 \\
\hline
\end{tabular}


To estimate the range of alternatives, positive ideal and negative solutions are calculated for each criterion
(Table 8).

Table 8. Positive and negative solution

\begin{tabular}{|c|c|c|c|c|c|c|c|c|c|c|c|c|c|}
\hline & $R_{1}\left(A_{i}\right)$ & $R_{2}\left(A_{i}\right)$ & $R_{3}\left(A_{i}\right)$ & $R_{4}\left(A_{i}\right)$ & $R_{5}\left(A_{i}\right)$ & $R_{6}\left(A_{i}\right)$ & $R_{7}\left(A_{i}\right)$ & $R_{8}\left(A_{i}\right)$ & $R_{9}\left(A_{i}\right)$ & $R_{10}\left(A_{i}\right)$ & $R_{11}\left(A_{i}\right)$ & $R_{12}\left(A_{i}\right)$ & $R_{13}\left(A_{i}\right)$ \\
\hline$A^{+}$ & 0.6031 & 0.5334 & 0.5519 & 0.7398 & 0.5508 & 0.6986 & 0.5084 & 0.7949 & 0.7585 & 0.6390 & 0.4879 & 0.6290 & 0.4785 \\
\hline$A^{-}$ & 0.2484 & 0.2546 & 0.2324 & 0.0462 & 0.2951 & 0.1354 & 0.3450 & 0.0954 & 0.0711 & 0.1302 & 0.3698 & 0.1973 & 0.3901 \\
\hline
\end{tabular}

After all of the above activities, all data must be compared to each other for each supplier to determine their ranking. Let us present the summary data of the methodology taking into account the ranking (Table 9).

Table 9. Summary of the methodology taking into account ranking

\begin{tabular}{|l|l|l|l|l|l|}
\hline \multicolumn{1}{|c|}{ Name } & $\mathrm{d}_{\mathrm{i}}{ }^{+}$ & $\mathrm{d}_{\mathrm{i}}{ }^{-}$ & $\mathrm{R}_{\mathrm{i}}$ & $\mathrm{R}\left(\mathrm{A}_{\mathrm{i}}\right)$ & Ранг \\
\hline Weatherford & 0.6652 & 1.3956 & 0.6772 & 0.6772 & 1 \\
\hline Tatneft & 1.2785 & 0.6402 & 0.3337 & 0.3337 & 4 \\
\hline Top-Co Inc. & 1.2857 & 0.6091 & 0.3214 & 0.3214 & 5 \\
\hline ZERS & 0.9181 & 0.9365 & 0.5050 & 0.5050 & 3 \\
\hline Art-Osnastka & 0.8716 & 1.0737 & 0.5520 & 0.5520 & 2 \\
\hline
\end{tabular}

The calculations confirm that according to the selected criteria the Weatherford is the best supplier. Let us present the innovative resource management model to the scientific community (Figure 1).

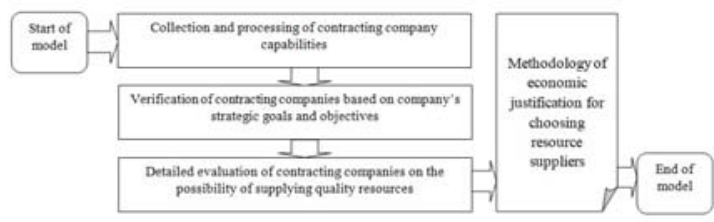

Figure 1. Innovative resource management model based on the methodology of economic justification for choosing resource suppliers for oil and gas enterprises

\section{Conclusion}

The authors of the paper proposed an innovationoriented model of resource management compiled on the basis of the methodology of economic justification for choosing resource suppliers for oil and gas enterprises.

\section{References}

1. F.M. Andiani, F. Abid, ,Hendri, A.S. Girsang, Advances in Science, Technology and Engineering Systems, 5 (6), 45-51(2020).

2 L.S. Bigelow, J.B. Barney, Journal of Management Studies, 58 (2), 528-539.

3. D. Biskupska, R.M. Chandima Ratnayake, IEEE International Conference on Industrial Engineering and Engineering Management, 8978660, 789-794 (2019)

4. S. Cartwright, I. Davies, C. Archer-Brown, Journal of Business Research, 125, 120-134 (2021).

5. M. Colucci, A. Vecchi, Business Strategy and the Environment, 30 (2), 856-873 (2021).
6. C. Dell'Era, D. Trabucchi, S. Magistretti, Creativity and Innovation Management, 30 (1) 31-46 (2021).

7. T. Frandsen, S.Ø. Boa, J.Z. Raja, International Journal of Production Research, 57 (22), 6977-6992 (2019).

8. H. Haaskjold, B. Andersen, O. Lædre, W. Aarseth International Journal of Managing Projects in Business, 13 (1), 197-230 (2019)

9. Ø. A. Mejlænder-Larsen Engineering, Construction and Architectural Management, 26 (4), pp. 648-667 (2019).

10. R. Nurcahyo, P.N. Dody, Z.Z.Z. Yadrifil, M. Habiburrahman, N. Wibowo, Proceedings of the International Conference on Industrial Engineering and Operations Management, (March), pp. 605-613. (2020)

11. S.V. Ponomareva, V.S. Kutuzova, \& A.A. Pavlovich. J. Mach. Manuf. Reliab. 49, 723-730 (2020). https://doi.org/10.3103/S1052618820080099.

12. S.V. Ponomareva, I.V. Zheleznova Journal of Physics: Conference Series. P.032106. (2018)

13. K.J. Sund, M.L.A.M. Bogers, M. Sahramaa Journal of Business Research, 128, 11-19 (2021)

14. S. Wood, German Journal of Human Resource Management, 35 (1), 83-113 (2021)

15. W.M. Zulhafiz, N.B.A. Rahman, International Journal of Business and Society, 21 (S1), 177-191 (2020). 